\title{
Diffuse Cystic Lung Diseases
}

\author{
Baha Obaidat, Dina Yazdani, Kathryn A Wikenheiser-Brokamp, and Nishant Gupta
}

\author{
Introduction \\ Lymphangioleiomyomatosis \\ Pulmonary Langerhans Cell Histiocytosis \\ Birt-Hogg-Dubé Syndrome \\ Cystic Lung Diseases Associated With Lymphoproliferative Disorders \\ Summary
}

\begin{abstract}
Diffuse cystic lung diseases (DCLDs) are a group of diverse pulmonary disorders with varying pathophysiology that are characterized by the presence of thin-walled, air-filled spaces within lung parenchyma. High-resolution computed tomography plays a crucial role in the evaluation of DCLDs, and cyst characteristics such as morphology, distribution, and the presence of other associated radiologic findings can help distinguish between different DCLDs. DCLDs can be classified according to their underlying pathophysiology as neoplastic, genetic, lymphoproliferative, infectious, associated with other forms of interstitial lung disease, or related to smoking. In this review we will provide a clinical overview on the most common DCLDs that are encountered in clinical practice: lymphangioleiomyomatosis, pulmonary Langerhans cell histiocytosis, Birt-Hogg-Dubé syndrome, and lymphoid interstitial pneumonia/follicular bronchiolitis, with a focus on practical aspects that can help clinicians in the optimal diagnosis and management of patients with DCLDs. Key words: lymphangioleiomyomatosis; pulmonary Langerhans cell histiocytosis; Birt-Hogg-Dubé syndrome; lymphoid interstitial pneumonia; follicular bronchiolitis. [Respir Care 2020;65(1):111-126. (C) 2020 Daedalus Enterprises]
\end{abstract}

\section{Introduction}

Diffuse cystic lung diseases (DCLDs) are a heterogeneous group of pulmonary disorders that are characterized by multiple air-filled spaces, or cysts, within the lung pa-

\footnotetext{
Drs Obaidat, Yazdani, and Gupta are affiliated with the Division of Pulmonary, Critical Care and Sleep Medicine, University of Cincinnati Medical Center, Cincinnati, Ohio. Dr Wikenheiser-Brokamp is affiliated with the Department of Pathology and Laboratory Medicine, University of Cincinnati College of Medicine, and the Division of Pathology \& Laboratory Medicine and Perinatal Institute, Division of Pulmonary Biology, Cincinnati Children's Hospital Medical Center, Cincinnati, Ohio.
}

Correspondence: Nishant Gupta MD, 231 Albert Sabin Way, MSB Room 6053, ML 0564, Cincinnati, OH 45267. E-mail: guptans@ucmail.uc.edu.

DOI: $10.4187 /$ respcare. 07117 renchyma. ${ }^{1}$ Cysts are thin-walled $(<2 \mathrm{~mm}$ wall thickness), spherical, air-filled lucencies interfaced with normal lung tissue (Table 1). ${ }^{2}$ Critical review of cyst characteristics such as shape, size, wall thickness, and distribution on high-resolution computed tomography (HRCT) plays a major role in the evaluation of DCLDs.

The exact mechanisms of cyst formation in DCLDs are not well elucidated and likely vary depending upon the underlying disease. Broadly, there are 3 major processes that have been linked to the development of cysts: (1) dilation of air spaces as a result of one-way obstruction in small airways leading to air entering but not exiting air spaces, ${ }^{3}(2)$ ischemia causing necrosis of small bronchioles, ${ }^{4}$ and (3) remodeling from matrix-degrading proteolytic enzymes. ${ }^{5}$ We have previously proposed a pathophysiology-based classification of DCLDs (Table 2). In this review, we will focus on the major DCLDs that a clinician is most likely to encounter in practice: lymphangioleiomyomatosis (LAM), pulmonary Langerhans 


\section{Diffuse Cystic Lung Diseases}

cell histiocytosis (PLCH), Birt-Hogg-Dubé syndrome (BHD), and lymphoid interstitial pneumonia (LIP)/follicular bronchiolitis (FB).

\section{Lymphangioleiomyomatosis}

Lymphangioleiomyomatosis (LAM) is a rare DCLD that predominantly affects women. ${ }^{6}$ The average age at diagnosis is $\sim 35 \mathrm{y},{ }^{1}$ but it has been reported in all age groups ranging from teenagers to elderly females. ${ }^{78}$ LAM occurs in 2 forms: in patients with the inheritable disease tuberous sclerosis complex (TSC-LAM), and in a sporadic form in patients without TSC. ${ }^{9}$ The estimated prevalence of LAM is $5-8$ per million women, ${ }^{10}$ although that is almost certainly an underestimate.

\section{Pathophysiology}

The central event driving the pathogenesis of LAM is a mutation in the TSC genes. Both TSC1 and TSC2 mutations have been described in patients with TSC-LAM, whereas only TSC2 mutations have been described in patients with sporadic LAM. TSC mutations are present in the germline in cases of TSC-LAM, while sporadic LAM patients have somatic mutations that is mutations limited to the abnormal cells only. This explains the transmission of TSC-LAM from one generation to the next, which is not seen in sporadic LAM. ${ }^{11}$ TSC1 and TSC2 translate into large proteins called hamartin and tuberin, respectively, which negatively regulate the intracellular serine/threonine kinase mTOR signaling pathway, which is responsible for regulating cell size, proliferation, and survival by assimilating signals from growth factors, energy, and stress. ${ }^{12}$ Therefore, hamartin or tuberin deficiency or dysfunction causes increased activity of mTOR, leading to inappropriate cell growth and proliferation..$^{13}$ Activated mTOR pathway drives proliferation of abnormal smooth muscle cells (LAM cells), arising from an unknown source of origin, and abnormal angiogenesis and lymphangiogenesis (in part) through expression of vascular endothelial growth factors (VEGF-C and VEGF-D), ${ }^{14}$ which leads to migration of LAM cells through the blood and lymphatic channels and ultimate deposition in the pulmonary parenchyma. In this regard, LAM behaves as a low-grade destructive metastatic neoplasm..$^{15}$ Once in the pulmonary parenchyma, the LAM cells lead to the formation of lymphatic clefts through a disordered remodeling process that occurs in response to inappropriate lymphangiogenic signaling with secretions of matrix-degrading enzymes, thus leading to the progressive cystic destruction of the lung tissue. ${ }^{16-18}$ Although the exact origin of LAM cells remains unknown, leading candidates include the uterus, ${ }^{19}$ kidneys, ${ }^{14}$ and pelvic lymph nodes. Given the striking female predominance of LAM, the role of female sex hormones such as estrogen in the pathogenesis of LAM has been proposed; estrogen has been shown to accentuate the metastatic potential of LAM cells in preclinical cell culture models and animal studies..$^{20,21}$

\section{Clinical Presentation}

Patients with LAM typically have one of the following modes of presentation: gradually worsening dyspnea, spontaneous pneumothorax, or incidental discovery of cysts on imaging performed for unrelated reasons. Pneumothoraces are seen in about $60-70 \%$ of LAM patients and tend to be recurrent. ${ }^{22}$ The most common pulmonary function test (PFT) abnormality in LAM is air-flow obstruction followed by decreased diffusion capacity of the lung for carbon monoxide $\left.\left(\mathrm{D}_{\mathrm{LCO}}\right)\right)^{23,24} \mathrm{It}$ has been suggested that patients who present with dyspnea may have more advanced disease and a greater risk of mortality as compared to patients presenting with a pneumothorax. ${ }^{25,26}$ This likely represents a form of lead-time bias as patients presenting with a pneumothorax tend to get diagnosed at a younger age compared to patients presenting with dyspnea. ${ }^{27}$

\section{Radiology}

Chest computed tomography (CT) scans in LAM classically show the presence of multiple, well-defined, round, thin-walled cysts, usually $2 \mathrm{~mm}$ to $2 \mathrm{~cm}$ in size, scattered throughout both lungs (Fig. 1, Table 3).28-30 Other less common findings include multifocal micronodular pneumocyte hyperplasia, a hamartomatous process of the lung that manifests radiologically as multiple small, discrete, solid and ground glass nodules and is seen mainly in patients with TSC-LAM. ${ }^{31}$ In patients with lymphatic involvement, interstitial chylous infiltrates and chylous pleural effusions might be present. Other extrathoracic manifestations of LAM include fatty tumors called angiomyolipomas (AMLs), which are seen most commonly in the kidneys, lymphadenopathy, fluid-filled cystic structures in the axial lymphatics (lymphangioleiomyomas), and chylous ascites. ${ }^{32-35}$ Renal AMLs can be seen in approximately one third of patients with sporadic LAM and 80 $90 \%$ of patients with TSC-LAM. ${ }^{34}$

\section{Pathology}

Histologic diagnosis of LAM relies on the presence of 2 key features: cystic change and LAM cells (Fig. 2). In early disease stages, the cysts and LAM cells may be inconspicuous, highlighting the need to correlate the pathology with clinical and radiologic findings. Small nests of LAM cells are typically located at the periphery of cysts. In more advanced disease, LAM cells form small nodules and infiltrate small airways and vessel walls, leading to vascular destruction and accumulation of hemosiderin-laden macrophages. LAM cell clusters, composed 


\section{Diffuse Cystic Lung Diseases}

of a LAM cell core surrounded by an outer lining of lymphatic endothelial cells, can be found within lymphatic channels in the lung as well as in chylous effusions, thus representing a mechanism for LAM cell dissemination. ${ }^{36}$ LAM cells are morphologically heterogeneous, consisting

Table 1. Fleischner Society Definitions of Air-Space Lucencies on CT Scan

\begin{tabular}{|c|c|}
\hline Lesion & Definition \\
\hline Cysts & $\begin{array}{l}\text { Thin-walled ( }<2 \mathrm{~mm} \text { wall thickness), spherical, } \\
\text { air-filled lucencies interfaced with normal lung }\end{array}$ \\
\hline Cavities & $\begin{array}{l}\text { Irregular, thick-walled, air-filled structures within } \\
\text { lung mass, consolidation, or nodule }\end{array}$ \\
\hline Bullae & $\begin{array}{l}\text { Thin-walled focal lucencies that are usually } \\
>1 \mathrm{~cm} \text { in diameter and are typically } \\
\text { associated with emphysematous changes }\end{array}$ \\
\hline Blebs & $\begin{array}{l}\text { Thin-walled, air-filled structures that are usually } \\
<1 \mathrm{~cm} \text { and are typically adjacent to the } \\
\text { visceral pleura }\end{array}$ \\
\hline Pneumatoceles & $\begin{array}{l}\text { Round, air-filled structures that are surrounded } \\
\text { by a thin wall and are usually caused by } \\
\text { infections, aspiration, or trauma }\end{array}$ \\
\hline \multicolumn{2}{|c|}{$\begin{array}{l}\text { Data from Reference } 2 . \\
\mathrm{CT}=\text { computed tomography }\end{array}$} \\
\hline
\end{tabular}

of haphazardly arranged bundles of spindle cells and cuboidal to oval epithelioid cells. LAM cells have a characteristic immunophenotype that is diffusely positive for smooth muscle actin and vimentin, with a subpopulation of LAM cells staining positively with the human melanoma black-45 (HMB-45) antibody developed against glycoprotein-10, a

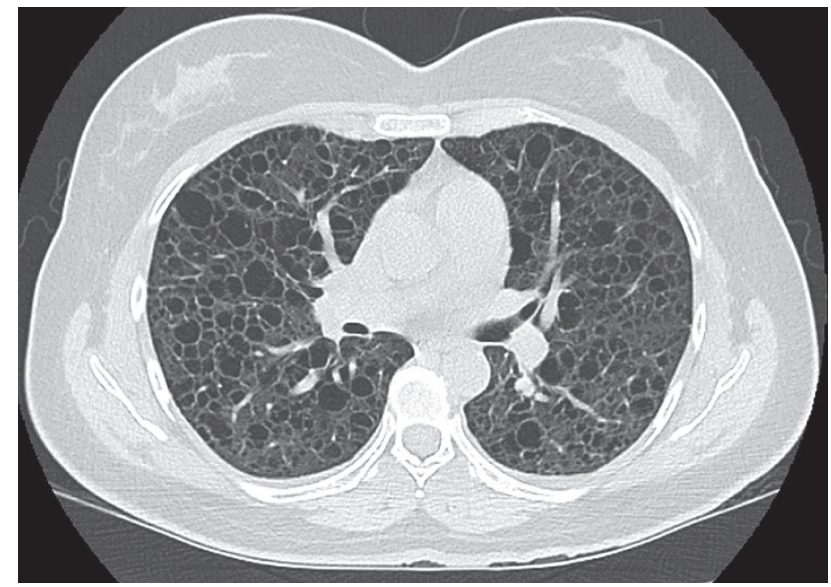

Fig. 1. Lymphangioleiomyomatosis. Computed tomography of the chest showing multiple, well-defined, round, thin-walled cysts scattered throughout both lungs.

Table 2. Classification of DCLDs

\begin{tabular}{|c|c|}
\hline Classification & Description \\
\hline 1. Neoplastic & $\begin{array}{l}\text { Lymphangioleiomyomatosis-sporadic as well as associated with tuberous sclerosis } \\
\text { Pulmonary Langerhans cell histiocytosis, and non-Langerhans cell histiocytoses, including } \\
\text { Erdheim Chester disease } \\
\text { Other primary and metastatic neoplasms, such as sarcomas, adenocarcinomas, } \\
\text { pleuropulmonary blastoma, etc. }\end{array}$ \\
\hline 2. Genetic/developmental/congenital & $\begin{array}{l}\text { Birt-Hogg-Dubé syndrome } \\
\text { Proteus syndrome, neurofibromatosis, Ehlers-Danlos syndrome } \\
\text { Congenital pulmonary airway malformation, bronchopulmonary dysplasia, etc. }\end{array}$ \\
\hline 3. Associated with lymphoproliferative disorders & $\begin{array}{l}\text { Lymphocytic interstitial pneumonia/Follicular bronchiolitis commonly seen in conjunction } \\
\text { with autoimmune disorders such as Sjögren syndrome, amyloidosis, and light-chain } \\
\text { deposition disease }\end{array}$ \\
\hline 4. Infectious & $\begin{array}{l}\text { Pneumocystis jiroveci, Staphylococcal pneumonia, recurrent respiratory papillomatosis, } \\
\text { endemic fungal diseases, especially coccidioidomycosis, paragonimiasis }\end{array}$ \\
\hline 5. Associated with interstitial lung diseases & $\begin{array}{l}\text { Hypersensitivity pneumonitis } \\
\text { Desquamative interstitial pneumonia }\end{array}$ \\
\hline 6. Smoking related & $\begin{array}{l}\text { Pulmonary Langerhans cell histiocytosis } \\
\text { Desquamative interstitial pneumonia } \\
\text { Respiratory bronchiolitis }\end{array}$ \\
\hline 7. Other/miscellaneous & $\begin{array}{l}\text { Post-traumatic pseudocysts } \\
\text { Fire-eater's lung } \\
\text { Hyper-IgE syndrome }\end{array}$ \\
\hline 8. DCLD mimics & $\begin{array}{l}\text { Emphysema } \\
\alpha 1 \text {-antitrypsin deficiency } \\
\text { Bronchiectasis } \\
\text { Honeycombing seen in late-stage scarring interstitial lung diseases }\end{array}$ \\
\hline
\end{tabular}


Diffuse Cystic Lung Diseases

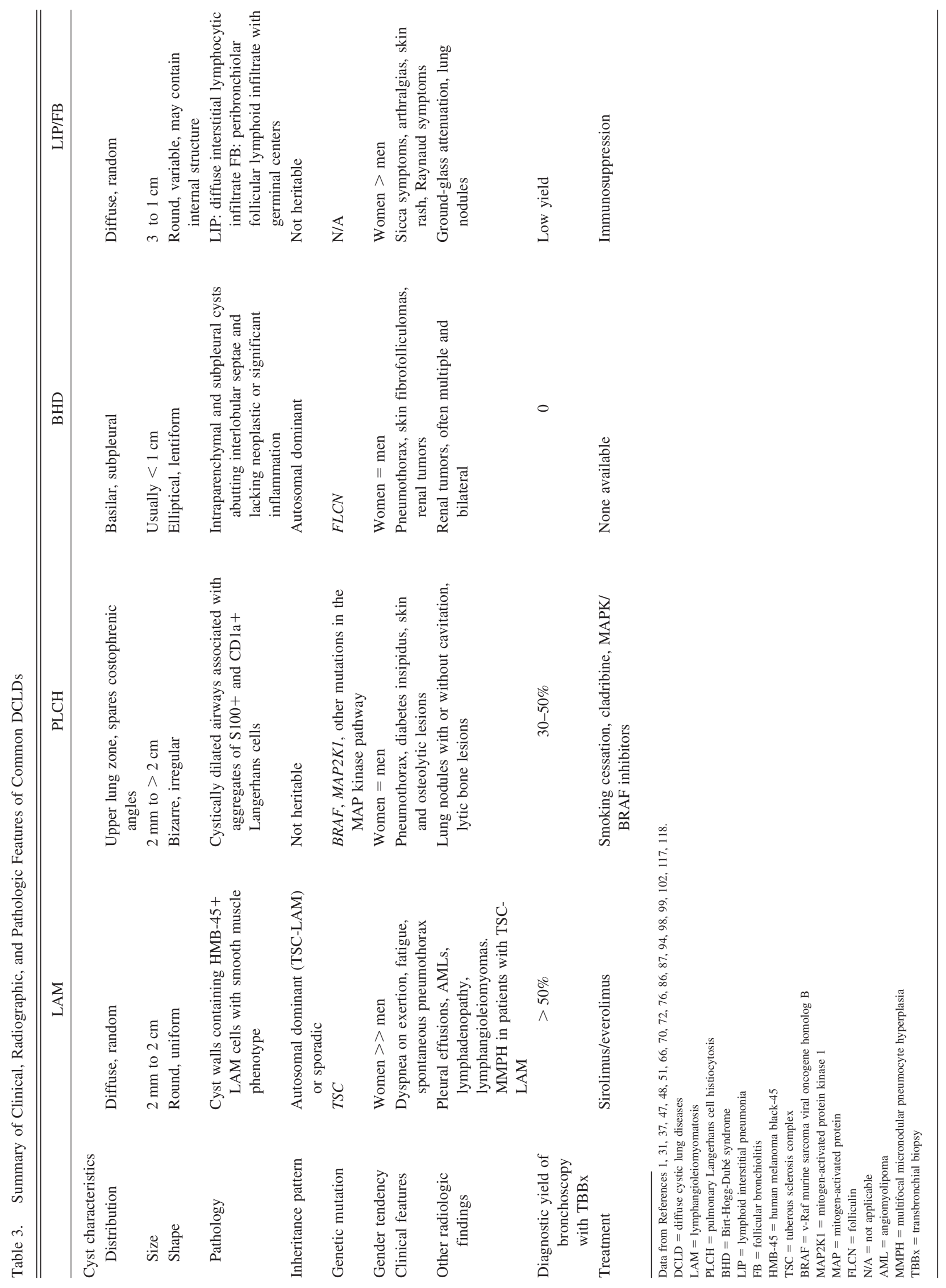




\section{Diffuse Cystic Lung Diseases}

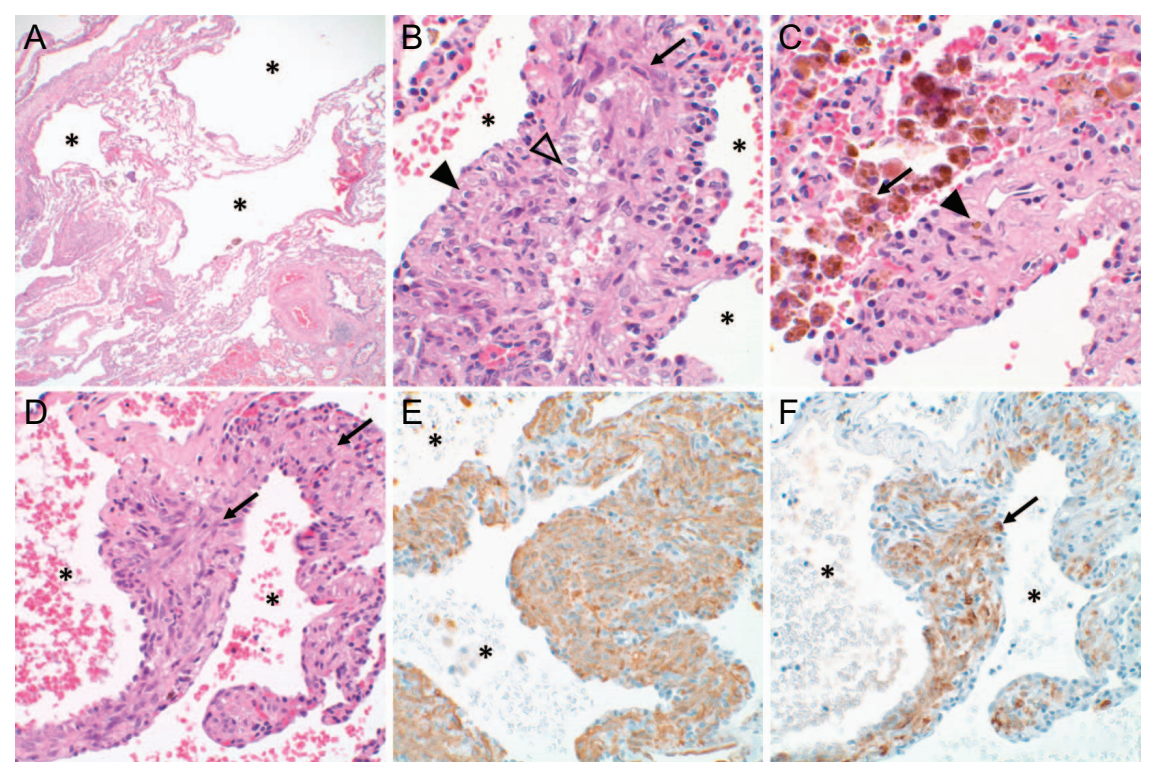

Fig. 2. Histopathology of lymphangioleiomyomatosis. (A) Multiple cystic spaces are seen at low magnification $\left({ }^{*}\right)(40 \times)$. (B) Higher magnification of cyst $\left({ }^{*}\right)$ wall showing a lymphangioleiomyomatosis (LAM) cell bundle composed of aggregates of bland, elongated, spindled cells (arrow) and round to oval epithelioid cells (arrowheads), some with clear cytoplasm (open arrowhead) (600X). (C) Hemosiderin is often present within alveolar macrophages in the air spaces (arrow) as well as in the interstitium (arrowhead) (600×). (D) The LAM cells (arrows) within the cyst (*) walls are positive for smooth muscle actin (SMA) $(400 \times)$ ). (E) SMA (brown stain) with a subpopulation of cells staining positively for the melanocytic marker, HMB-45 (400×). (F) Brown stain and arrow indicates cells staining positively for HMB-45 (400 $\times$ ).

premelanosomal protein. ${ }^{37}$ LAM cells also stain positive for estrogen and progesterone receptors. ${ }^{38}$

\section{Diagnosis}

The diagnosis of LAM should be considered in any woman who presents with unexplained progressive dyspnea or spontaneous pneumothorax. ${ }^{39-41}$ In women with a known diagnosis of TSC, it is recommended that screening HRCT be performed starting at the age of $18 \mathrm{y}$ to look for the presence of LAM. ${ }^{42}$ The presence of characteristic cystic change on HRCT in conjunction with TSC is considered sufficient to establish a clinical diagnosis of LAM. ${ }^{43,44}$ In patients with suspected sporadic LAM, it is essential to perform a detailed physical examination to evaluate for the presence of underlying TSC because adultonset diagnosis of TSC is not uncommon. ${ }^{6}$ Serum VEGF-D levels are elevated in $\sim 70 \%$ of patients with sporadic LAM and are nearly $100 \%$ specific for the diagnosis of LAM in patients with cystic lung disease on HRCT. In the United States, serum VEGF-D levels can be obtained in a College of American Pathologists/Clinical Laboratory Improvement Amendments approved manner at the Translational Trial Development and Support Laboratory (TTDSL; available at: https://www.cincinnatichildrens.org/research/ cores/translational-core-laboratory/translational-trialdevelopment-support-laboratory. Accessed September 2, 2019) and should be obtained prior to performing invasive diagnostic procedures. ${ }^{44-46}$ Renal AMLs can be seen in about one third of patients with sporadic LAM and can help establish diagnosis of LAM without needing a lung biopsy. Similarly, other lymphatic manifestations such as chylous fluid collections and lymphangioleiomyomas can be seen in $\sim 20 \%$ of sporadic LAM patients and obviate the need for lung biopsy. In total, the diagnosis of LAM can be established with the above-mentioned noninvasive measures in $70-80 \%$ of patients. In the absence of one of the above-mentioned criteria, lung biopsy may be required to confirm the diagnosis of LAM. It is worth highlighting that, in certain situations, especially patients with mild disease who would not warrant initiation of pharmacotherapy, a probable diagnosis of LAM with serial monitoring may be a reasonable strategy. In cases where a definite diagnosis is needed, transbronchial lung biopsy has a yield of $>60 \%$, appears to be safe based on small series, ${ }^{47-49}$ and should be performed prior to pursuing surgical lung biopsy. ${ }^{50}$ Critical review of the pathology by an expert pathologist is essential to avoid false negatives on biopsy. An algorithmic approach to establishing the diagnosis of LAM has recently been published.50

\section{Management}

Improved understanding of the pathobiology of LAM has led to rapid advancements in disease management. In May 2015, the U.S. Food and Drug Administration (FDA) 


\section{Diffuse Cystic Lung Diseases}

approved sirolimus, an mTOR inhibitor for the treatment of LAM. The approval was based largely on the findings of the Multi-center International LAM Efficacy of Sirolimus (MILES) trial, a double-blind, randomized, parallelgroup trial of $1 \mathrm{y}$ of treatment with sirolimus versus placebo, followed by 1 y of observation. Subjects who were treated with placebo lost $\sim 10 \%$ of their lung function over the course of the treatment year, whereas subjects who received sirolimus had stable lung function and improved functional performance. ${ }^{51}$ The recently published American Thoracic Society/Japanese Respiratory Society LAM Clinical Practice Guidelines recommend that sirolimus be initiated for patients with LAM who have $\mathrm{FEV}_{1}$ $\leq 70 \%$ of predicted, problematic chylous effusions, or rapidly progressive disease or substantial disease burden. ${ }^{44}$ Because the effect of the drug is suppressive rather than curative, most patients are maintained on treatment indefinitely. In the clinical experience that has accumulated since the publication of MILES results, sirolimus appears to have durable safety and efficacy, and a majority of the LAM patients tend to exhibit a beneficial response to treatment with sirolimus.

Further trials are underway to assess the risks and benefits of treating patients in early disease stages (MILED, NCT03150914) and to elucidate the ideal dose and duration of therapy. Several early-stage clinical trials involving novel agents, either alone or in combination with sirolimus, are either underway or have recently been completed: aromatase inhibitors (NCT01353209), 52 combined hydroxychloroquine and sirolimus (NCT01687179), ${ }^{53} \mathrm{com}-$ bination of sirolimus and simvastatin (NCT02061397), combined resveratrol and sirolimus (NCT03253913), celecoxib (NCT02484664), imatinib (NCT03131999), and nintedanib (NCT03062943). We are optimistic that results from these studies will help further refine management of LAM in the near future.

Given the high risk of pneumothorax recurrence in LAM patients (ipsilateral recurrence $>70 \%$ ), pleurodesis should be performed after the first pneumothorax episode. ${ }^{54}$ Ipsilateral recurrence rate after pleurodesis is reduced by $\sim 50 \%$ and ranges between $27 \%$ and $32 \%$ (Table 4). ${ }^{54}$ It is important to note that prior pleurodesis is not a contraindication for future lung transplantation. ${ }^{50,55}$ Patients with LAM should be counseled to avoid smoking (Table 5). Exogenous estrogen can accelerate disease progression in LAM, and patients should be counseled to avoid hormonal therapies containing estrogen. LAM patients should stay up to date with their vaccinations, including influenza and pneumococcal vaccines. Finally, lung transplantation remains a viable option for patients with progressive endstage LAM that does not respond to other therapies. ${ }^{56,57}$ Recommendations for the optimal diagnosis and management of LAM have been published ${ }^{43,44,50}$ and are a valuable resource for clinicians to guide effective decision mak-
Table 4. Pneumothorax in DCLDs

\begin{tabular}{|c|c|c|c|}
\hline & LAM & PLCH & BHD \\
\hline Prevalence of spontaneous pneumothorax & $55-73$ & $10-20$ & $25-75$ \\
\hline Ipsilateral pneumothorax recurrence rate & 73 & 56 & 73 \\
\hline $\begin{array}{l}\text { Contralateral pneumothorax occurrence } \\
\text { rate }\end{array}$ & 74 & 29 & 48 \\
\hline $\begin{array}{l}\text { Ipsilateral recurrence rate after } \\
\text { conservative management }\end{array}$ & 66 & 58 & 63 \\
\hline $\begin{array}{l}\text { Ipsilateral recurrence rate after chemical } \\
\text { pleurodesis }\end{array}$ & 27 & Unknown & 30 \\
\hline $\begin{array}{l}\text { Ipsilateral recurrence rate after surgical } \\
\text { pleurodesis }\end{array}$ & 32 & $0-20$ & 35 \\
\hline $\begin{array}{l}\text { Data are presented as } \% \text {. Data from References } 26,34 \text {, } \\
\text { DCLD = diffuse cystic lung diseases } \\
\text { LAM = lymphangioleiomyomatosis } \\
\text { PLCH = pulmonary Langerhans cell histiocytosis } \\
\text { BHD = Birt-Hogg-Dubé syndrome }\end{array}$ & $4,79,85$ & 2, 119. & \\
\hline
\end{tabular}

Table 5. General Recommendations Applicable to All Patients With DCLDs

1. Counsel to avoid smoking.

2. Stay up to date on vaccination including annual influenza vaccination and both pneumococcal (PPSV23 and PCV13) vaccines.

3. Air travel is safe for most patients with DCLDs. The risk of inflight pneumothorax is approximately 1 per 100 flights. Patients should be educated about the typical symptoms of pneumothorax and instructed to seek medical attention if they have new-onset symptoms suggestive of a pneumothorax.

4. Advise against scuba diving due to the potential risk of spontaneous pneumothorax.

5. Patients presenting with spontaneous pneumothorax should undergo pleurodesis following the first episode of pneumothorax. Prior pleurodesis is not a contraindication for lung transplantation.

Data from References 120-124.

DCLD $=$ diffuse cystic lung diseases

ing when evaluating patients with suspected or confirmed LAM.

\section{Prognosis}

Several prognostic biomarkers in the progression of LAM have been implicated in previous studies, including baseline PFT values, ${ }^{24}$ menopausal status, ${ }^{24}$ symptomatology at presentation, ${ }^{58} \mathrm{CT}$ findings, ${ }^{59}$ association with TSC, ${ }^{59}$ response to bronchodilators, ${ }^{60}$ and VEGF-D levels. ${ }^{61} \mathrm{~A}$ recently published longitudinal analysis of 217 LAM patients enrolled in the National Heart, Lung and Blood Institute LAM Registry has shown 5-, 10-, 15-, and 20-y transplant-free survival rates of $94 \%, 85 \%, 75 \%$, and $64 \%$, respectively, with a median survival $>20$ y. Baseline PFTs and menopausal status were associated with future risk of progression to death or transplantation. ${ }^{27}$ Similar 


\section{Diffuse Cystic Lung Diseases}
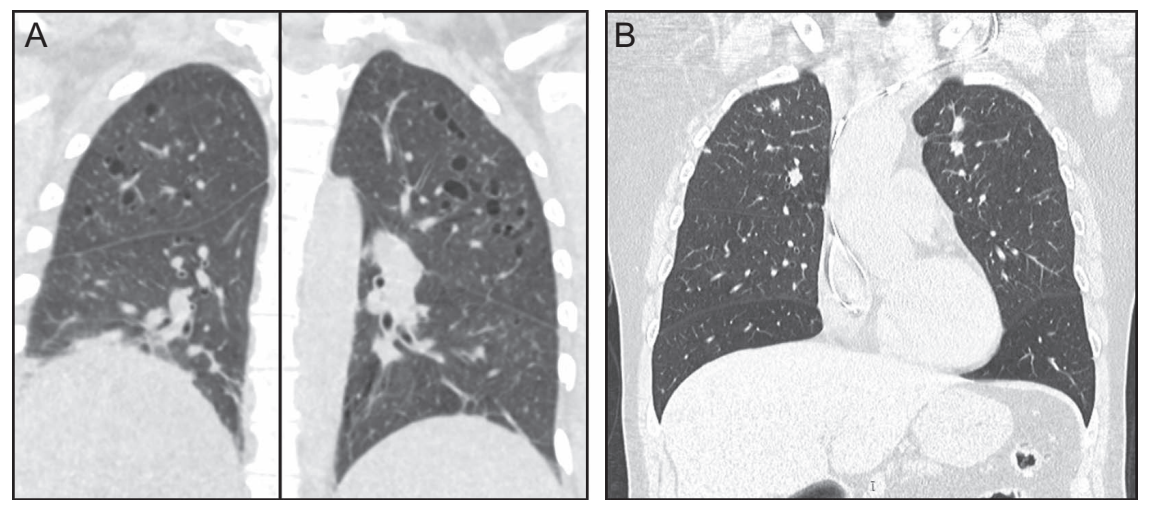

Fig. 3. Pulmonary Langerhans cell histiocytosis (PLCH). Computed tomography of the chest typically shows a combination of nodules and cysts predominantly seen in upper and middle lung zones with characteristic costophrenic angle sparing. (A) Cystic predominant PLCH. (B) Nodular predominant PLCH.

results with regard to the impact of menopausal status on the rate of disease progression were also noted in a recent post hoc analysis of the MILES cohort. ${ }^{62}$

\section{Pulmonary Langerhans Cell Histiocytosis}

Pulmonary Langerhans cell histiocytosis (PLCH) is a rare DCLD that is thought to be caused by tobacco smoking because it almost exclusively affects current or previous smokers. ${ }^{63}$ In some cases, PLCH might present as a multisystem disease involving other organs, most commonly bones and pituitary.

\section{Pathophysiology}

PLCH was previously thought to occur as a result of polyclonal proliferation of Langerhans cells induced by cigarette smoke; differentiated subpopulation of macrophages that regulates mucosal airway immunity. ${ }^{64,65} \mathrm{How}-$ ever, pathogenic activating mutations in the mitogen-activating protein (MAP) kinase pathway, especially BRAF V600E, have recently been described in $>50 \%$ of the lesional dendritic cells in subjects with PLCH. ${ }^{66}$ This discovery has transformed our understanding of the pathogenesis of PLCH, and it is now considered to be an inflammatory myeloid neoplasm, where cigarette smoke induces the abnormal proliferation and migration of MAP kinase-mutated dendritic cells to the lungs, leading to the development of PLCH. Secondary activation of the immune system and subsequent destruction of the bronchiolar walls by matrix-degrading enzymes also plays a key role in the development of the hallmark peribronchiolar nodules, cavities, and eventual cystic destruction. ${ }^{5}$

\section{Clinical Presentation}

Patients usually present with cough, dyspnea, pleuritic chest pain, and occasionally hemoptysis or spontaneous pneumothorax. Many patients with PLCH remain asymptomatic, and PLCH findings are noted incidentally on chest imaging. ${ }^{67}$ In early stages of the disease, PFTs may be normal or exhibit mild restriction; in later stages, obstructive defects are common, along with air trapping and reduction in $\mathrm{D}_{\mathrm{LCO}}{ }^{67}$ In cases of multisystemic Langerhans cell histiocytosis, patients might present with skin rash, lytic bone lesions, or diabetes insipidus.

\section{Radiology}

Chest CT findings typically include a combination of nodules and cysts. PLCH nodules are usually $1-10 \mathrm{~mm}$ in size and are typically centered around the bronchioles. Cysts in PLCH usually appear in later stages of the disease, can vary in wall thickness from typical thin-walled cysts to thick-walled cavities, and tend to spare the bases of the lungs (Fig. 3, Table 3). Other radiologic findings emanating from concomitant cigarette smoke-induced lung damage such as emphysema, ground-glass opacities suggestive of respiratory bronchiolitis/Desquamative interstitial pneumonia, or reticular opacities are occasionally seen in patients with PLCH. ${ }^{68}$ PLCH lesions, especially nodules, can be fluorodeoxyglucose (FDG)-avid, making it difficult to differentiate between PLCH and other malignant conditions on the basis of FDG-positron emission tomography. ${ }^{69}$

\section{Pathology}

The classic histopathology for PLCH is a patchy, peribronchiolar nodular infiltrate composed of clusters of dendritic cells admixed with variable numbers of other cell types including lymphocytes, macrophages, and eosinophils (Fig. 4). Central cavities can form within the nodules, which may represent dilation of the former bronchiolar lumen. The inflammatory infiltrate extends into the 


\section{Diffuse Cystic Lung Diseases}

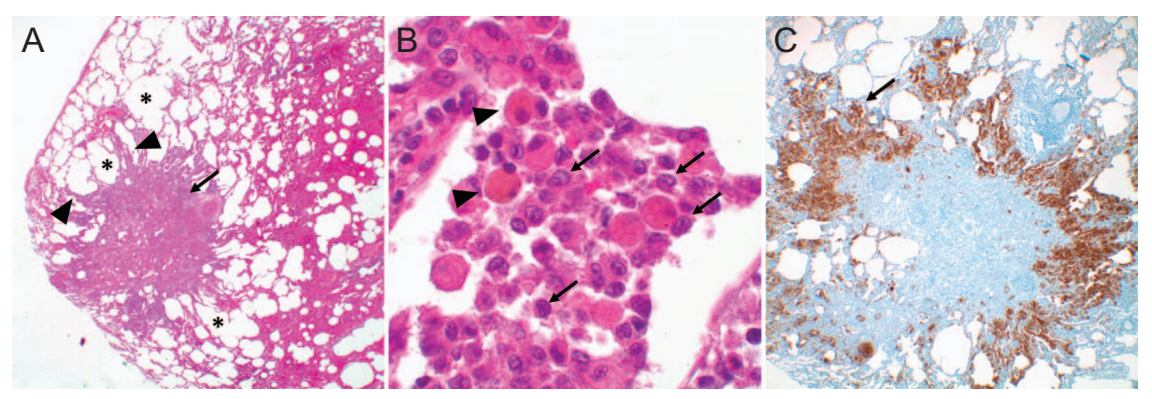

Fig. 4. Nodular lesion in patient with Langerhans cell histiocytosis. (A) Well circumscribed nodular infiltrate (arrow) with infiltrate extending into the adjacent alveolar septa (arrowhead) producing the characteristic stellate configuration. Some of the surrounding air spaces are enlarged $\left(^{*}\right)$ due to traction caused by fibrosis within the lesion $(20 \times)$. (B) High magnification of diagnostic aggregates of Langerhans cells with eosinophilic cytoplasm and characteristic folded and kidney bean shaped nuclei (arrows). Pigmented macrophages associated with cigarette smoking (arrowheads) are frequently found within the inflammatory infiltrate and in surrounding alveolar spaces (1,000 $\times)$. (C) The Langerhans cells stain positively for S-100, Langerin, and CD1a (arrow). The Langerhans cells in lesions with a mixed inflammatory infiltrate and background fibrosis with collagen deposition as in this case are often most prominent in the interstitium at the periphery of the nodule $(40 \times)$.

surrounding alveolar septa, resulting in the characteristic stellate configuration. Fibrosis with collagen deposition can also be present within the nodules, leading to traction and enlargement of the surrounding air spaces. In advanced $\mathrm{PLCH}$, fibrosis may be the predominant component with only few dendritic cell aggregates at the periphery or only a stellate scar suggesting the diagnosis of PLCH. The key diagnostic feature of PLCH is the presence of Langerhanslike cell clusters. Scattered interstitial Langerhans-like cells that are common in normal lungs and can be increased in association with smoking are not diagnostic of PLCH. Pathogenic Langerhans-like cells in PLCH are characterized as bland appearing cells with a moderate amount of eosinophilic cytoplasm and distinctive folded or kidneyshaped nuclei. The cells stain positively for S100 protein, Langerin, and CD1a. ${ }^{70}$ Histopathologic features of other smoking-related lung diseases are commonly seen in PLCH, including respiratory bronchiolitis, Desquamative interstitial pneumonia and smoking-related interstitial fibrosis.

\section{Diagnosis}

In some cases, the diagnosis of PLCH might be sufficiently made on the basis of a CT scan if all of the classic pulmonary findings are present along with history of smoking. In other cases where the diagnosis is questionable, further tests might be required, including bronchoscopy with bronchoalveolar lavage and biopsy. Although it has a high false negative rate, bronchoalveolar lavage showing $>5 \% \mathrm{CD} 1 \mathrm{~A}+$ cells is strongly suggestive of PLCH. A more definitive diagnosis requires tissue confirmation either via transbronchial or surgical lung biopsy. ${ }^{47,71}$

\section{Management}

The mainstay of PLCH management is smoking cessation, with reports of disease stabilization and even regres- sion reported after smoking cessation. ${ }^{72-74}$ However, a subset of patients with PLCH $(\sim 30 \%)$ continue to decline even after successful smoking cessation. The inability to prospectively identify this subset highlights the importance of close, longitudinal PFT monitoring for patients with PLCH. ${ }^{75}$ Multiple chemotherapeutic regimens have been tried in patients with PLCH with limited success. Currently, the most promising treatment approaches include cladribine $^{76,77}$ and targeted treatment aimed at the MAP kinase pathway. ${ }^{78}$ About $20 \%$ of patients with PLCH experience a spontaneous pneumothorax (Table 4). The risk of recurrence is high $(\sim 60 \%)$ if managed conservatively, ${ }^{79}$ thus patients with PLCH should undergo pleurodesis following the first episode of spontaneous pneumothorax rather than wait for a recurrent event and undergo periodic evaluation for the development of pulmonary hypertension. Management of PLCH-associated pulmonary hypertension can be difficult and best performed at expert referral centers. Lung transplantation is a viable option in advanced disease. ${ }^{80}$

\section{Prognosis}

The long-term prognosis and overall survival of patients with PLCH is not well established; however, retrospective case series have reported median survival times of 12.5$13 \mathrm{y}$ from the time of diagnosis. ${ }^{67,81}$ The development of pulmonary hypertension in patients with PLCH has been associated with worse outcomes. ${ }^{82,83}$ Other reported factors associated with poor outcomes include older age, low $\mathrm{FEV}_{1}$, reduced $\mathrm{FEV}_{1} / \mathrm{FVC}$, high residual volume, and reduced $\mathrm{D}_{\mathrm{LCO}}{ }^{67,81}$ Continued smoking has a deleterious impact on the rate of disease progression, and successful smoking cessation has been shown to reduce the rate of disease progression. ${ }^{84}$ Further clarity regarding the natural history of disease progression in PLCH and identification 


\section{Diffuse Cystic Lung Diseases}

of biomarkers that can help predict the subset of patients at increased risk of disease progression remains a future research priority for PLCH.

\section{Birt-Hogg-Dubé Syndrome}

Birt-Hogg-Dubé Syndrome (BHD) is a rare autosomaldominant disease that is characterized by lung cysts, hair follicle tumors, and renal tumors. Lung cysts from BHD are usually seen in the fourth decade of life, with $80 \%$ penetrance by the age of $50 \mathrm{y} \cdot{ }^{85,86}$

\section{Pathophysiology}

BHD is caused by mutations in the Folliculin gene $(F L C N)$, which encodes folliculin, a tumor-suppressor protein. The exact pathophysiology of pulmonary cyst formation in BHD is unclear; some of the candidate pathways that have been proposed in the pathogenesis of pulmonary cystogenesis include the mTOR signaling pathway, E-cadherin-LKBP1-AMPK signaling, increased cell-cell adhesion, and increased mechanical stress on the alveolar-septal regions in the anatomically weak lung areas. ${ }^{87-90}$

\section{Clinical Presentation}

Pulmonary involvement from BHD can be detected either incidentally or following a spontaneous pneumothorax. The prevalence of spontaneous pneumothorax in patients with BHD has been variably reported to range between $25 \%$ and $75 \% .86,91,92$ Spontaneous pneumothorax in patients with BHD has been reported in the absence of radiologically visible cysts on chest $\mathrm{CT} .{ }^{93}$ PFTs generally show preserved spirometric parameters including $\mathrm{FEV}_{1}$, $\mathrm{FVC}$, and $\mathrm{FEV}_{1} / \mathrm{FVC}$, and a mild reduction in $\mathrm{D}_{\mathrm{LCO}}$ is seen in some advanced cases. ${ }^{94}$ Skin lesions including fibrofolliculomas and trichodiscomas are the most common manifestation of BHD, found in $\sim 90 \%$ of the patients. ${ }^{91,95}$ Typical BHD skin lesions are whitish, dome-shaped papules that measure $1-5 \mathrm{~mm}$ in size and are usually seen on the facies and upper torso. Renal tumors are seen in up to $27 \%$ of patients with BHD (oncocytomas and chromophobe renal carcinoma are the most common), who have an average age of $50 \mathrm{y}$ at diagnosis. ${ }^{96}$

\section{Radiology and Pathology}

Pulmonary cysts are present in $\sim 80 \%$ of the adult patients with BHD. BHD lung cysts classically present as multiple, thin-walled cysts that range widely in size, are variable in shape (round to lentiform), and are usually found at the bases, often abutting the pleural surface and pulmonary vasculature (Fig. 5, Table 3). ${ }^{97}$ BHD lung cysts are predominantly subpleural or paraseptal in location by

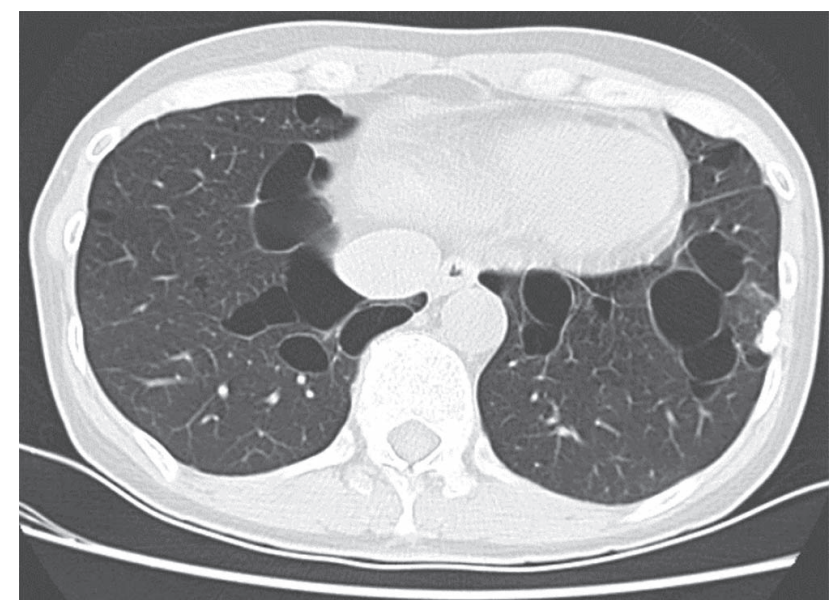

Fig. 5. In Birt-Hogg-Dubé syndrome (BHD), lung cysts can range widely in size, often have an oval or lentiform shape, and are usually found at the lung bases, often abutting the pleura or pulmonary vasculature.

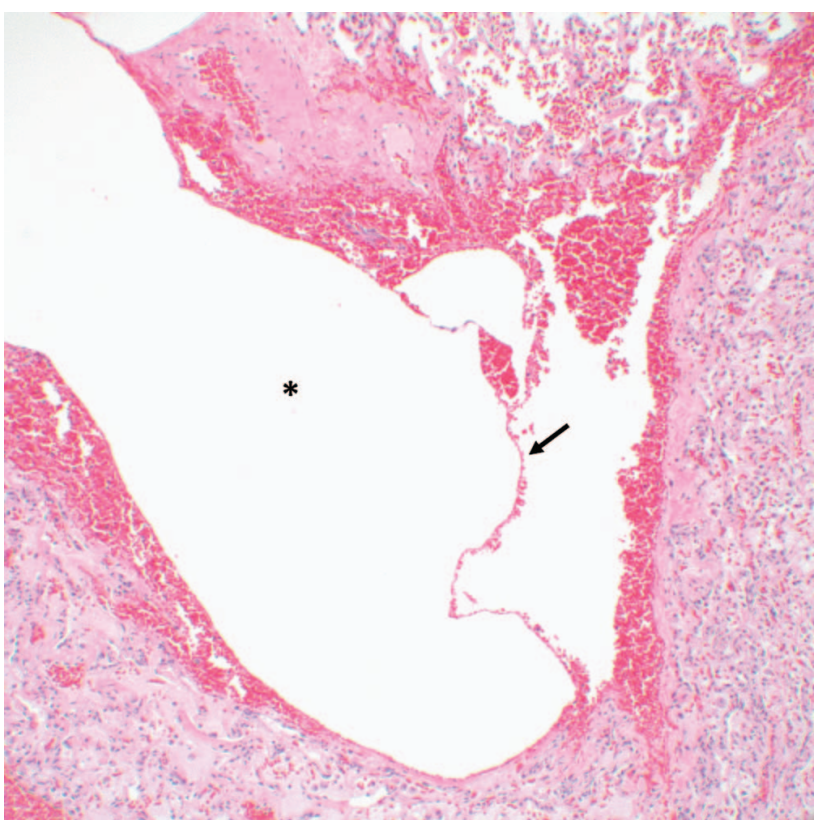

Fig. 6. Lung cyst from a patient with Birt-Hogg-Dubé syndrome. A paraseptal cyst $\left(^{*}\right)$ surrounded by compressed lung parenchyma without significant inflammation, fibrosis, or cellular proliferations. A thin intracystic septum (arrow) traverses the cyst (100×).

histologic evaluation and are surrounded by normal thin alveolar walls without associated cellular proliferations, significant inflammation, or fibrosis (Fig. 6). The cysts can be difficult to distinguish from emphysema based on histopathology; however, in contrast to smoking-related emphysema, BHD cysts predominantly occur in the lower rather than upper lobes, and the surrounding parenchyma can be compressed but is characteristically normal. Additionally, in a study of 229 pulmonary cysts in 50 subjects 
with BHD, 88.2\% of BHD lung cysts abutted interlobular septa and $13.6 \%$ were found to have intracystic septa with occasional venules protruding into the cysts. ${ }^{87}$ These features along with the location of the cysts in the lower lobes, the lack of significant inflammation and fibrosis, and the absence of cellular proliferations are key characteristics that distinguish BHD from other DCLDs. The diagnosis of BHD should thus be considered in any case with multiple, lower lobe-predominant, nondescript cysts, especially in nonsmokers.

\section{Diagnosis}

Young patients who present with spontaneous pneumothorax along with a personal or family history of skin lesions, pneumothorax, or renal cancer should be evaluated for BHD. Careful skin examination should be performed for all patients with suspected BHD, with a low threshold for dermatological evaluation and skin biopsy of suspicious lesions, especially the lesions in characteristic places such as the face and upper torso. Detection of fibrofolliculomas on skin biopsy in conjunction with typical chest CT findings can be sufficient to make a clinical diagnosis of BHD. It is important to note, however, that there is wide phenotypic variability in the clinical manifestations of BHD, and the absence of skin or kidney lesions does not preclude the possibility of underlying BHD. Detection of pathogenic FLCN mutations from the peripheral blood is required to establish a confirmed genetic diagnosis of BHD. Given the high penetrance of FLCN gene mutations, screening asymptomatic family members is recommended. Diagnostic criteria for BHD have previously been published by us and by others. ${ }^{98,99}$

\section{Management and Prognosis}

Patients should be reassured that cysts from BHD typically occupy a small percentage of the lung parenchyma, do not cause physiological impairment, and tend to stay stable over time. Management of pulmonary involvement from BHD is typically centered on the increased risk of spontaneous pneumothoraces. Although the exact prevalence of spontaneous pneumothorax in BHD has been variably reported to range between $25 \%$ and $75 \%, 86,100$ there is an extremely high risk of recurrence $(\sim 75 \%)$ if managed conservatively (Table 4). ${ }^{86,100}$ Thus, patients with BHD presenting with a spontaneous pneumothorax should undergo pleurodesis following the first episode of pneumothorax rather than waiting for a recurrent episode. Patients with BHD should be screened regularly for renal tumors, starting at age $21 \mathrm{y}$. Magnetic resonance imaging is the best modality for screening due to the risk of cumulative radiation exposure from CT scans and the lack of sensitivity for detecting small lesions with ultrasound. ${ }^{101}$ In patients with no detectable lesion on the screening scan, further imaging can be performed every three years. More frequent imaging may be needed in patients with kidney lesion(s), with the frequency dictated by the size, morphology, and imaging characteristics of the underlying lesion(s).

\section{Cystic Lung Diseases Associated With Lymphoproliferative Disorders}

\section{Lymphoid Interstitial Pneumonia/Follicular Bronchiolitis}

Lymphoid interstitial pneumonia (LIP) is a form of interstitial lung disease that results from lymphocytic infiltration of the lung parenchyma. ${ }^{102}$ Follicular bronchiolitis (FB) is characterized by hyperplasia of lymphoid follicles along the walls of bronchioles and blood vessels consistent with a lymphatic distribution. ${ }^{103}$ The majority of LIP and FB cases are associated with rheumatologic disorders (especially Sjögren syndrome, systemic lupus erythematosus, and rheumatoid arthritis), immunodeficiencies (including common variable immunodeficiency), and viral infections (like Epstein-Barr virus and human immunodeficiency virus). ${ }^{104}$

Pathophysiology and Clinical Presentation. LIP and FB constitute a pathophysiologic spectrum of lymphocytic infiltration from hyperplasia of bronchus-associated lymphoid tissue. The association of LIP and FB with rheumatologic disorders and immunodeficiencies suggests that bronchus-associated lymphoid tissue hyperplasia might represent cellular response to a variety of intrinsic and extrinsic stimuli. ${ }^{103}$ Patients with LIP and FB usually present with nonspecific symptoms including cough, dyspnea, fatigue, fever, and weight loss. PFTs typically show a restrictive pattern with reduced $\mathrm{D}_{\mathrm{LCO}} \cdot{ }^{104}$ Because most cases of LIP and FB are associated with underlying connective tissue diseases, these patients may also have other symptoms including rash, sicca symptoms, Raynaud's, and other findings of individual connective tissue diseases.

Radiology and Pathology. Chest CT might show findings of ground glass opacities and centrilobular and subpleural nodules in addition to lung cysts. Cysts in LIP usually have a diffuse random distribution and often contain internal structures and eccentric vessels that can help distinguish LIP from other forms of DCLDs (Fig. 7). ${ }^{105,106}$ Tissue examination in LIP shows diffuse infiltration of alveolar septa by a mixture of small lymphocytes, plasma cells, and macrophages, typically with little or no fibrosis. Lymphoid follicles with germinal centers are often present. The lymphocytes are predominantly $\mathrm{T}$ cells with scattered $\mathrm{B}$ cells except within the germinal centers, where B cells are prominent. ${ }^{102}$ Alveolar spaces may be distorted and contain proteinaceous material along with scattered lymphocytes and macrophages. ${ }^{107}$ Oc- 


\section{Diffuse Cystic Lung Diseases}

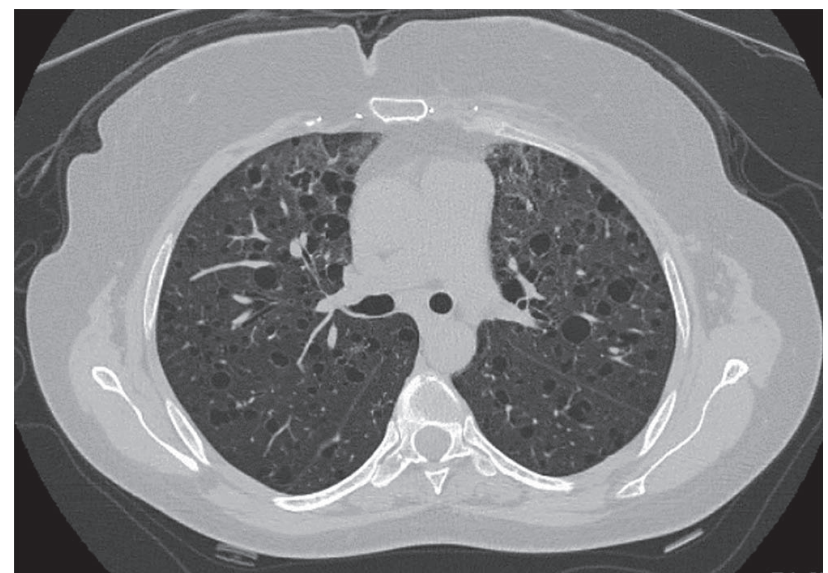

Fig. 7. Lymphoid interstitial pneumonia (LIP) in a patient with Sjögren syndrome. Cysts in LIP usually have diffuse random distribution, round or oval shape, and are variable in size, and they are frequently are associated with eccentric vessels and intracystic septations or structures.

casionally loose granulomas are present, but well-formed granulomas are not seen. ${ }^{107}$ In FB, numerous lymphoid follicles with reactive germinal centers are seen in a peribronchial and peribronchiolar distribution ${ }^{103}$ (Fig. 8). Bronchiolar lumens are often narrowed by the inflammatory nodules. In some cases, the cellular infiltrate extends beyond the peribronchiolar interstitium, involving the alveolar septa focally rather than the diffuse involvement diagnostic of LIP, which supports the concept that FB and LIP represent entities along a shared disease spectrum. ${ }^{102,103}$ Careful histopathologic evaluation is important to rule out other lymphoid disorders including lymphoma. Flow cytometry, immunohistochemical staining, and analysis for clonality are helpful for this purpose $^{102,107}$

Diagnosis. The diagnosis of LIP and FB can be established on clinical grounds in patients with characteristic cystic changes on HRCT and the presence of underlying autoimmune disease such as Sjögren syndrome. ${ }^{106} \mathrm{In}$ some cases, however, cystic changes from LIP/FB can be the presenting manifestation of underlying Sjögren syndrome, and the serologies may be falsely negative. In unclear cases, surgical lung biopsy may be needed to establish a histopathological diagnosis. ${ }^{104}$

Management. LIP is usually treated with steroids and cytotoxic agents. The ground glass attenuation and nodules associated with LIP respond well to immune suppression, but the effect of these treatments on cystic changes is unclear. ${ }^{108}$ LIP secondary to human immunodeficiency virus infection may improve with initiation of highly active antiretroviral therapy. ${ }^{109}$ There is an increased risk of development of lymphoma, and repeat chest imaging should be conducted periodically (eg, every 3-5 y) in these patients; providers should maintain a low threshold for biopsy in case of new or enlarging nodules or consolidative opacities.

\section{Amyloidosis}

Amyloidosis refers to a group of disorders characterized by abnormal deposition of amyloid fibrils. This could present as a systemic disorder or as a localized disorder. Localized pulmonary amyloidosis usually presents with pulmonary nodules, but in rare cases it may present with diffuse cystic changes. ${ }^{110}$ Lung amyloidosis could be seen with Sjögren syndrome, which might be associated with mucosa-associated lymphoid tissue lymphoma in some cases. ${ }^{111}$ Diagnosis of pulmonary amyloidosis requires histopathological examination by lung biopsy. Amyloid material is typified as globular irregular deposits of amorphous eosinophilic glassy material on routine histologic stain. A collection of macrophages known as foreign-body giant cell response to the amyloid is commonly present along with occasional calcification or ossification. Chronic inflammation may be present with clusters of plasma cells with monoclonal staining for kappa or lambda immunoglobulin light chains. Congo red staining with apple green birefringence under polarized light, immunohistochemical staining for amyloid proteins, or electron microscopy findings of thin amyloid fibrils can aid in the diagnosis. Liquid chromatography and tandem mass spectrophotometry can be used to subtype the amyloid.

\section{Light-Chain Deposition Disease (LCDD)}

Light-chain deposition disease (LCDD) is a rare disease that is characterized by deposition of a non-fibrillary amorphous material in alveolar walls and small airways. Contrary to amyloidosis, this acellular material does not have $\beta$-pleated sheet configuration and therefore does not bind Congo red stain. ${ }^{112}$ In rare instances, LCDD can have isolated pulmonary involvement; however, LCDD is usually associated with multiple myeloma and other lymphoproliferative disorders, and renal involvement resulting in proteinuria is common among patients. ${ }^{113}$ LCDD lung cysts vary in size and shape and could resemble LAM or PLCH on chest radiography. ${ }^{114}$ LCDD is usually a progressive disorder that results in respiratory failure. Treatment involves treating the underlying lymphoproliferative disorder (if present), with lung transplantation being an option for advanced cases. ${ }^{114-116}$

\section{Summary}

DCLD on chest imaging carries a broad differential diagnosis and can occur as a result of multiple pathophysiologically distinct disease processes. The presence of cysts in the pulmonary parenchyma creates unique physiologi- 


\section{Diffuse Cystic Lung Diseases}
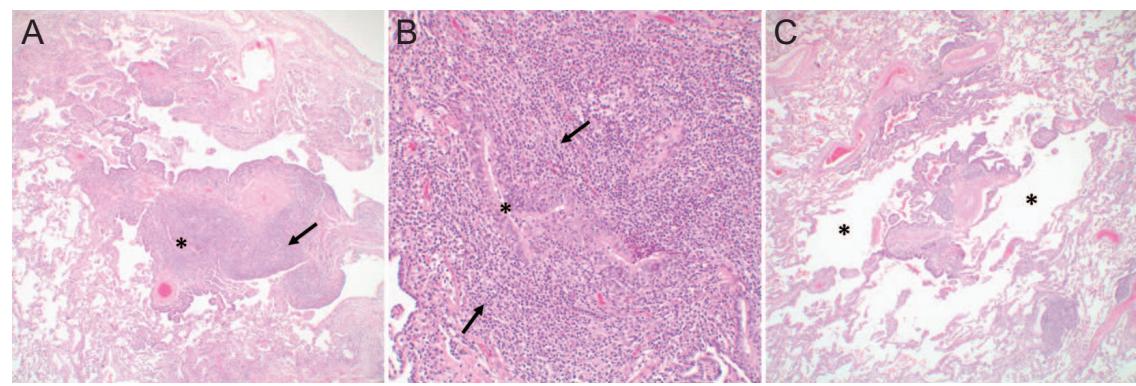

Fig. 8. Follicular bronchiolitis and cystic spaces in a patient with Sjögren syndrome. (A) Dense lymphoid infiltrate with germinal centers (arrow) surrounding a bronchiole $\left(^{*}\right)(40 \times)$. (B) Higher magnification of the bronchiole in $(A)$ showing narrowing of the bronchiolar lumen by the prominent chronic inflammatory infiltrate (arrows) $(200 \times)$. (C) Markedly inflamed bronchiole with cystically dilated air spaces $\left(^{*}\right)$ surrounding the bronchiole $(40 \times)$.

Table 6. Respiratory Care Implications for DCLD Patients

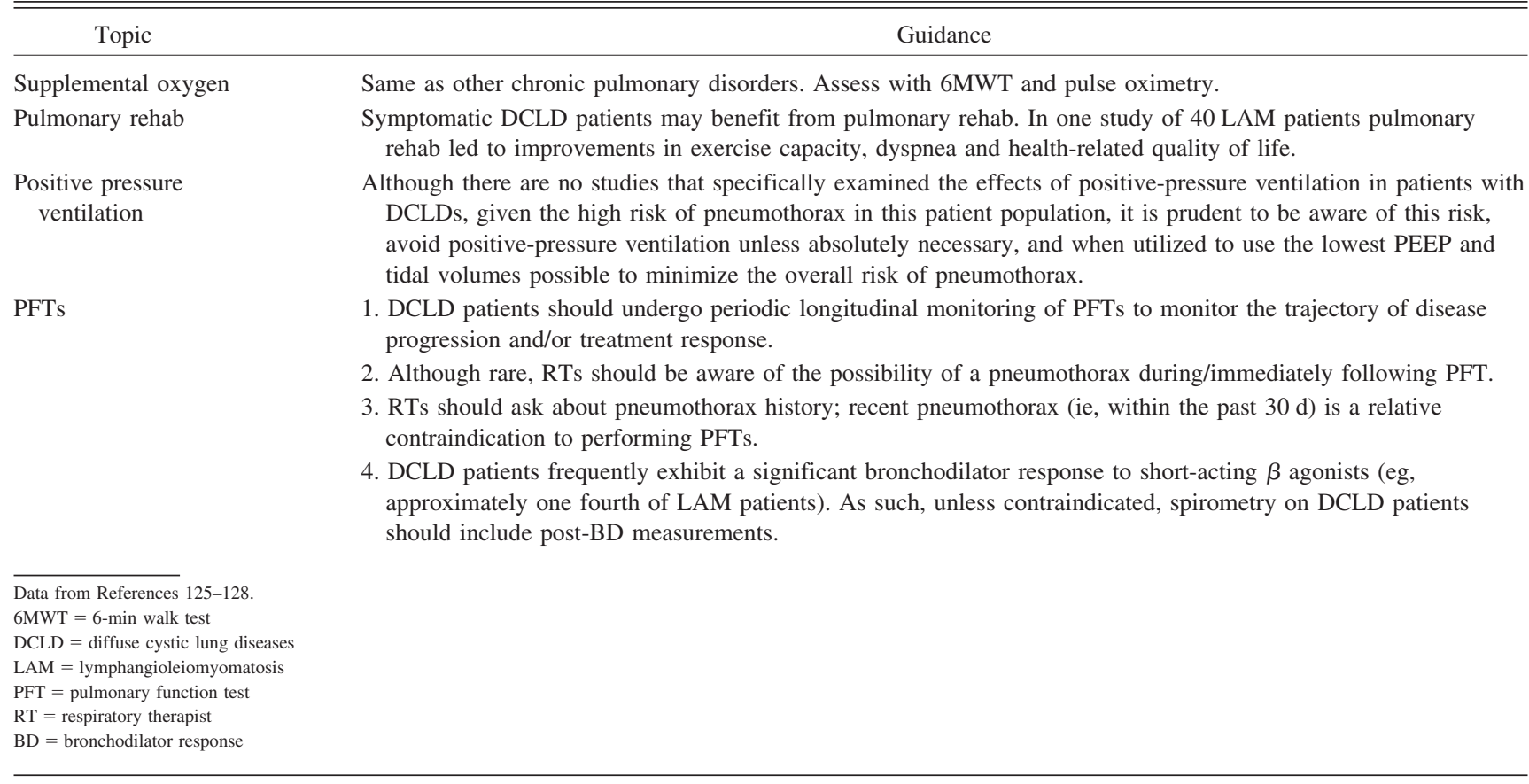

cal and clinical implications for respiratory providers, including respiratory therapists (Table 6). Establishing the correct diagnosis is crucial because DCLDs vary widely in clinical course, prognosis and treatment. Chest HRCT remains the most important noninvasive tool for evaluation of DCLDs. Careful and systematic evaluation of the cyst characteristics on HRCT, integrated with clinical, laboratory, and histopathology (if available) features can help narrow the field and guide the clinician toward the right path in the diagnosis and management of these patients.

\section{REFERENCES}

1. Gupta N, Vassallo R, Wikenheiser-Brokamp KA, McCormack FX. Diffuse cystic lung disease. Part I. Am J Respir Crit Care Med 2015;191(12):1354-1366.
2. Hansell DM, Bankier AA, MacMahon H, McLoud TC, Müller NL, Remy J. Fleischner Society: glossary of terms for thoracic imaging. Radiology 2008;246(3):697-722.

3. Kikuchi E, Kinoshita I, Yamazaki K, Itoh T, Shimizu T, Shimizu H, Nishimura M. Epithelioid sarcoma presenting as pulmonary cysts with cancer antigen 125 expression. Respirology 2006;11(6):826829.

4. Ohdama S, Akagawa S, Matsubara O, Yoshizawa Y. Primary diffuse alveolar septal amyloidosis with multiple cysts and calcification. Eur Respir J 1996;9(7):1569-1571.

5. Colombat M, Caudroy S, Lagonotte E, Mal H, Danel C, Stern M, et al. Pathomechanisms of cyst formation in pulmonary light chain deposition disease. Eur Respir J 2008;32(5):1399-1403.

6. Taveira-DaSilva AM, Moss J. Clinical features, epidemiology, and therapy of lymphangioleiomyomatosis. Clin Epidemiol 2015;7:249257.

7. Ciftci AO, Sanlialp I, Tanyel FC, Buyukpamukçu N. The association of pulmonary lymphangioleiomyomatosis with renal and he- 


\section{Diffuse Cystic Lung Diseases}

patic angiomyolipomas in a prepubertal girl: a previously unreported entity. Respiration 2007;74(3):335-337.

8. Ho TB, Hull JH, Hughes NC. An 86-year-old female with lymphangioleiomyomatosis. Eur Respir J 2006;28(5):1065.

9. Crino PB, Nathanson KL, Henske EP. The tuberous sclerosis complex. N Engl J Med 2006;355(13):1345-1356.

10. Harknett EC, Chang WY, Byrnes S, Johnson J, Lazor R, Cohen $\mathrm{MM}$, et al. Use of variability in national and regional data to estimate the prevalence of lymphangioleiomyomatosis. QJM 2011; 104(11):971-979.

11. Slingerland JM, Grossman RF, Chamberlain D, Tremblay CE. Pulmonary manifestations of tuberous sclerosis in first degree relatives. Thorax 1989;44(3):212-214.

12. Rosner M, Hanneder M, Siegel N, Valli A, Hengstschläger M. The tuberous sclerosis gene products hamartin and tuberin are multifunctional proteins with a wide spectrum of interacting partners. Mutat Res 2008;658(3):234-246.

13. Sengupta S, Peterson TR, Sabatini DM. Regulation of the mTOR complex 1 pathway by nutrients, growth factors, and stress. Mol Cell 2010;40(2):310-322.

14. Henske EP, McCormack FX. Lymphangioleiomyomatosis: a wolf in sheep's clothing. J Clin Invest 2012;122(11):3807-3816.

15. Henske EP. Metastasis of benign tumor cells in tuberous sclerosis complex. Genes Chromosomes Cancer 2003;38(4):376-381.

16. Krymskaya VP, Shipley JM. Lymphangioleiomyomatosis: a complex tale of serum response factor-mediated tissue inhibitor of metalloproteinase-3 regulation. Am J Respir Cell Mol Biol 2003;28(5): 546-550.

17. Zhe X, Yang Y, Jakkaraju S, Schuger L. Tissue inhibitor of metalloproteinase-3 downregulation in lymphangioleiomyomatosis: potential consequence of abnormal serum response factor expression. Am J Respir Cell Mol Biol 2003;28(4):504-511.

18. Dongre A, Clements D, Fisher AJ, Johnson SR. Cathepsin K in lymphangioleiomyomatosis: LAM cell-fibroblast interactions enhance protease activity by extracellular acidification. Am J Pathol 2017;187(8):1750-1762.

19. Hayashi T, Kumasaka T, Mitani K, Terao Y, Watanabe M, Oide T, et al. Prevalence of uterine and adnexal involvement in pulmonary lymphangioleiomyomatosis: a clinicopathologic study of 10 patients. Am J Surg Pathol 2011;35(12):1776-1785.

20. Li C, Lee PS, Sun Y, Gu X, Zhang E, Guo Y, et al. Estradiol and mTORC2 cooperate to enhance prostaglandin biosynthesis and tumorigenesis in TSC2-deficient LAM cells. J Exp Med 2014;211(1): 15-28.

21. Yu JJ, Robb VA, Morrison TA, Ariazi EA, Karbowniczek M, Astrinidis A, et al. Estrogen promotes the survival and pulmonary metastasis of tuberin-null cells. Proc Natl Acad Sci USA 2009; 106(8):2635-2640.

22. Steagall WK, Glasgow CG, Hathaway OM, Avila NA, TaveiraDasilva AM, Rabel A, et al. Genetic and morphologic determinants of pneumothorax in lymphangioleiomyomatosis. Am J Physiol Lung Cell Mol Physiol 2007;293(3):L800-L808.

23. Taveira-DaSilva AM, Stylianou MP, Hedin CJ, Kristof AS, Avila NA, Rabel A, et al. Maximal oxygen uptake and severity of disease in lymphangioleiomyomatosis. Am J Respir Crit Care Med 2003; 168(12):1427-1431.

24. Taveira-DaSilva AM, Stylianou MP, Hedin CJ, Hathaway O, Moss $\mathrm{J}$. Decline in lung function in patients with lymphangioleiomyomatosis treated with or without progesterone. Chest 2004;126(6):18671874.

25. Cohen MM, Pollock-BarZiv S, Johnson SR. Emerging clinical picture of lymphangioleiomyomatosis. Thorax 2005;60(10):875-879.

26. Hayashida M, Seyama K, Inoue Y, Fujimoto K, Kubo K, Respiratory Failure Research Group of the Japanese Ministry of Health,
Labor, and Welfare. The epidemiology of lymphangioleiomyomatosis in Japan: a nationwide cross-sectional study of presenting features and prognostic factors. Respirology 2007;12(4):523-530.

27. Gupta N, Lee HS, Ryu JH, Taveira-DaSilva AM, Beck GJ, Lee JC, et al. The NHLBI LAM registry: prognostic physiologic and radiologic biomarkers emerge from a 15 -year prospective longitudinal analysis. Chest 2019;155(2):288-296.

28. Merchant RN, Pearson MG, Rankin RN, Morgan WK. Computerized tomography in the diagnosis of lymphangioleiomyomatosis. Am Rev Respir Dis 1985;131(2):295-297.

29. Avila NA, Chen CC, Chu SC, Wu M, Jones EC, Neumann RD, Moss J. Pulmonary lymphangioleiomyomatosis: correlation of ventilation-perfusion scintigraphy, chest radiography, and CT with pulmonary function tests. Radiology 2000;214(2):441-446.

30. Avila NA, Kelly JA, Dwyer AJ, Johnson DL, Jones EC, Moss J. Lymphangioleiomyomatosis: correlation of qualitative and quantitative thin-section CT with pulmonary function tests and assessment of dependence on pleurodesis. Radiology 2002;223(1):189197.

31. Harari S, Torre O, Moss J. Lymphangioleiomyomatosis: what do we know and what are we looking for? Eur Respir Rev 2011; 20(119):34-44.

32. Avila NA, Kelly JA, Chu SC, Dwyer AJ, Moss J. Lymphangioleiomyomatosis: abdominopelvic CT and US findings. Radiology 2000;216(1):147-153.

33. Matsui K, Tatsuguchi A, Valencia J, Yu Z, Bechtle J, Beasley MB, et al. Extrapulmonary lymphangioleiomyomatosis (LAM): clinicopathologic features in 22 cases. Hum Pathol 2000;31(10):12421248.

34. Ryu JH, Moss J, Beck GJ, Lee JC, Brown KK, Chapman JT, et al. The NHLBI lymphangioleiomyomatosis registry: characteristics of 230 patients at enrollment. Am J Respir Crit Care Med 2006;173(1): $105-111$

35. Urban T, Lazor R, Lacronique J, Murris M, Labrune S, Valeyre D, Cordier JF. Pulmonary lymphangioleiomyomatosis. A study of 69 patients. Groupe d'Etudes et de Recherche sur les Maladies "Orphelines" Pulmonaires (GERM“"O”P). Medicine (Baltimore) 1999; 78(5):321-337.

36. Kumasaka T, Seyama K, Mitani K, Souma S, Kashiwagi S, Hebisawa A, et al. Lymphangiogenesis-mediated shedding of LAM cell clusters as a mechanism for dissemination in lymphangioleiomyomatosis. Am J Surg Pathol 2005;29(10):1356-1366.

37. Matsumoto Y, Horiba K, Usuki J, Chu SC, Ferrans VJ, Moss J. Markers of cell proliferation and expression of melanosomal antigen in lymphangioleiomyomatosis. Am J Respir Cell Mol Biol 1999;21(3):327-336.

38. Gao L, Yue MM, Davis J, Hyjek E, Schuger L. In pulmonary lymphangioleiomyomatosis expression of progesterone receptor is frequently higher than that of estrogen receptor. Virchows Arch 2014;464(4):495-503.

39. Hagaman JT, Schauer DP, McCormack FX, Kinder BW. Screening for lymphangioleiomyomatosis by high-resolution computed tomography in young, nonsmoking women presenting with spontaneous pneumothorax is cost-effective. Am J Respir Crit Care Med 2010;181(12):1376-182.

40. Northrup H, Krueger DA, Group ITSCC. Tuberous sclerosis complex diagnostic criteria update: recommendations of the 2012 International Tuberous Sclerosis Complex Consensus Conference. Pediatr Neurol 2013;49(4):243-254.

41. Ryu JH, Hartman TE, Torres VE, Decker PA. Frequency of undiagnosed cystic lung disease in patients with sporadic renal angiomyolipomas. Chest 2012;141(1):163-168.

42. Krueger DA, Northrup H, Group ITSCC. Tuberous sclerosis complex surveillance and management: recommendations of the 2012 


\section{Diffuse Cystic Lung Diseases}

International Tuberous Sclerosis Complex Consensus Conference. Pediatr Neurol 2013;49(4):255-265.

43. Johnson SR, Cordier JF, Lazor R, Cottin V, Costabel U, Harari S, et al. European Respiratory Society guidelines for the diagnosis and management of lymphangioleiomyomatosis. Eur Respir J 2010; 35(1):14-26

44. McCormack FX, Gupta N, Finlay GR, Young LR, Taveira-DaSilva AM, Glasgow CG, et al. Official American Thoracic Society/Japanese Respiratory Society clinical practice guidelines: lymphangioleiomyomatosis diagnosis and management. Am J Respir Crit Care Med 2016;194(6):748-761.

45. Young LR, Inoue Y, McCormack FX. Diagnostic potential of serum VEGF-D for lymphangioleiomyomatosis. N Engl J Med 2008; 358(2):199-200.

46. Young LR, Vandyke R, Gulleman PM, Inoue Y, Brown KK, Schmidt LS, et al. Serum vascular endothelial growth factor-D prospectively distinguishes lymphangioleiomyomatosis from other diseases. Chest 2010;138(3):674-681.

47. Harari S, Torre O, Cassandro R, Taveira-DaSilva AM, Moss J. Bronchoscopic diagnosis of Langerhans cell histiocytosis and lymphangioleiomyomatosis. Respir Med 2012;106(9):1286-1292.

48. Meraj R, Wikenheiser-Brokamp KA, Young LR, Byrnes S, McCormack FX. Utility of transbronchial biopsy in the diagnosis of lymphangioleiomyomatosis. Front Med 2012;6(4):395-405.

49. Koba T, Arai T, Kitaichi M, Kasai T, Hirose M, Tachibana K, et al. Efficacy and safety of transbronchial lung biopsy for the diagnosis of lymphangioleiomyomatosis: a report of 24 consecutive patients. Respirology 2018;23(3):331-338.

50. Gupta N, Finlay GA, Kotloff RM, Strange C, Wilson KC, Young LR, et al. Lymphangioleiomyomatosis diagnosis and management: high-resolution chest computed tomography, transbronchial lung biopsy, and pleural disease management. An official American Thoracic Society/Japanese Respiratory Society clinical practice guideline. Am J Respir Crit Care Med 2017;196(10):1337-1348.

51. McCormack FX, Inoue Y, Moss J, Singer LG, Strange C, Nakata K, et al. Efficacy and safety of sirolimus in lymphangioleiomyomatosis. N Engl J Med 2011;364(17):1595-1606.

52. Lu C, Lee HS, Pappas GP, Dilling DF, Burger CD, Shifren A, et al. A phase II clinical trial of an aromatase inhibitor for postmenopausal women with lymphangioleiomyomatosis. Ann Am Thorac Soc 2017;14(6):919-928.

53. El-Chemaly S, Taveira-Dasilva A, Goldberg HJ, Peters E, Haughey M, Bienfang D, et al. Sirolimus and autophagy inhibition in lymphangioleiomyomatosis: results of a phase i clinical trial. Chest 2017;151(6):1302-1310.

54. Almoosa KF, Ryu JH, Mendez J, Huggins JT, Young LR, Sullivan EJ, et al. Management of pneumothorax in lymphangioleiomyomatosis: effects on recurrence and lung transplantation complications. Chest 2006;129(5):1274-1281.

55. Weill D, Benden C, Corris PA, Dark JH, Davis RD, Keshavjee S, et al. A consensus document for the selection of lung transplant candidates: 2014-an update from the Pulmonary Transplantation Council of the International Society for Heart and Lung Transplantation. J Heart Lung Transplant 2015;34(1):1-15.

56. Kpodonu J, Massad MG, Chaer RA, Caines A, Evans A, Snow NJ, Geha AS. The US experience with lung transplantation for pulmonary lymphangioleiomyomatosis. J Heart Lung Transplant 2005; 24(9):1247-1253.

57. Ussavarungsi K, Hu X, Scott JP, Erasmus DB, Mallea JM, Alvarez F, et al. Mayo clinic experience of lung transplantation in pulmonary lymphangioleiomyomatosis. Respir Med 2015;109(10):13541359.
58. Oprescu N, McCormack FX, Byrnes S, Kinder BW. Clinical predictors of mortality and cause of death in lymphangioleiomyomatosis: a population-based registry. Lung 2013;191(1):35-42.

59. Taveira-DaSilva AM, Pacheco-Rodriguez G, Moss J. The natural history of lymphangioleiomyomatosis: markers of severity, rate of progression and prognosis. Lymphat Res Biol 2010;8(1):9-19.

60. Taveira-DaSilva AM, Hedin C, Stylianou MP, Travis WD, Matsui K, Ferrans VJ, Moss J. Reversible airflow obstruction, proliferation of abnormal smooth muscle cells, and impairment of gas exchange as predictors of outcome in lymphangioleiomyomatosis. Am J Respir Crit Care Med 2001;164(6):1072-1076.

61. Young L, Lee HS, Inoue Y, Moss J, Singer LG, Strange C, et al. Serum VEGF-D a concentration as a biomarker of lymphangioleiomyomatosis severity and treatment response: a prospective analysis of the Multicenter International Lymphangioleiomyomatosis Efficacy of Sirolimus (MILES) trial. Lancet Respir Med 2013;1(6): 445-452.

62. Gupta N, Lee HS, Young LR, Strange C, Moss J, Singer LG, et al. Analysis of the MILES cohort reveals determinants of disease progression and treatment response in lymphangioleiomyomatosis. Eur Respir J 2019;53(4):1802066.

63. Howarth DM, Gilchrist GS, Mullan BP, Wiseman GA, Edmonson JH, Schomberg PJ. Langerhans cell histiocytosis: diagnosis, natural history, management, and outcome. Cancer 1999;85(10):2278-2290.

64. Tazi A, Bonay M, Bergeron A, Grandsaigne M, Hance AJ, Soler P. Role of granulocyte-macrophage colony stimulating factor (GM$\mathrm{CSF}$ ) in the pathogenesis of adult pulmonary histiocytosis X. Tho$\operatorname{rax}$ 1996;51(6):611-614.

65. Tazi A, Moreau J, Bergeron A, Dominique S, Hance AJ, Soler P. Evidence that Langerhans cells in adult pulmonary Langerhans cell histiocytosis are mature dendritic cells: importance of the cytokine microenvironment. J Immunol 1999;163(6):3511-3515.

66. Sahm F, Capper D, Preusser M, Meyer J, Stenzinger A, Lasitschka $\mathrm{F}$, et al. BRAFV600E mutant protein is expressed in cells of variable maturation in Langerhans cell histiocytosis. Blood 2012; 120(12):e28-e34.

67. Vassallo R, Ryu JH, Schroeder DR, Decker PA, Limper AH. Clinical outcomes of pulmonary Langerhans'-cell histiocytosis in adults. N Engl J Med 2002;346(7):484-490.

68. Abbott GF, Rosado-de-Christenson ML, Franks TJ, Frazier AA, Galvin JR. From the archives of the AFIP: pulmonary Langerhans cell histiocytosis. Radiographics 2004;24(3):821-841.

69. Krajicek BJ, Ryu JH, Hartman TE, Lowe VJ, Vassallo R. Abnormal fluorodeoxyglucose PET in pulmonary Langerhans cell histiocytosis. Chest 2009;135(6):1542-1549.

70. Sholl LM, Hornick JL, Pinkus JL, Pinkus GS, Padera RF. Immunohistochemical analysis of Langerin in Langerhans cell histiocytosis and pulmonary inflammatory and infectious diseases. Am J Surg Pathol 2007;31(6):947-952.

71. Baqir M, Vassallo R, Maldonado F, Yi ES, Ryu JH. Utility of bronchoscopy in pulmonary Langerhans cell histiocytosis. J Bronchology Interv Pulmonol 2013;20(4):309-312.

72. Ninaber M, Dik H, Peters E. Complete pathological resolution of pulmonary Langerhans cell histiocytosis. Respirol Case Rep 2014; 2(2):76-78.

73. Mogulkoc N, Veral A, Bishop PW, Bayindir U, Pickering CA, Egan JJ. Pulmonary Langerhans' cell histiocytosis: radiologic resolution following smoking cessation. Chest 1999;115(5):1452-1455.

74. Sawalha L, Kumar A, Arshad A, Mador MJ. Pulmonary Langerhans cell histiocytosis: radiologic resolution following cessation of second hand smoking. Clin Respir J 2017;11(6):1063-1067.

75. Tazi A, Marc K, Dominique S, de Bazelaire C, Crestani B, Chinet $\mathrm{T}$, et al. Serial computed tomography and lung function testing in 


\section{Diffuse Cystic Lung Diseases}

pulmonary Langerhans' cell histiocytosis. Eur Respir J 2012;40(4): 905-912.

76. Grobost V, Khouatra C, Lazor R, Cordier JF, Cottin V. Effectiveness of cladribine therapy in patients with pulmonary Langerhans cell histiocytosis. Orphanet J Rare Dis 2014;9:191.

77. Lorillon G, Bergeron A, Detourmignies L, Jouneau S, Wallaert B, Frija J, Tazi A. Cladribine is effective against cystic pulmonary Langerhans cell histiocytosis. Am J Respir Crit Care Med 2012; 186(9):930-932.

78. Lorillon G, Jouenne F, Baroudjian B, de Margerie-Mellon C, Vercellino L, Meignin V, et al. Response to trametinib of a pulmonary Langerhans cell histiocytosis harboring a MAP2K1 deletion. Am J Respir Crit Care Med 2018;198(5):675-678.

79. Mendez JL, Nadrous HF, Vassallo R, Decker PA, Ryu JH. Pneumothorax in pulmonary Langerhans cell histiocytosis. Chest 2004; 125(3):1028-1032.

80. Dauriat G, Mal H, Thabut G, Mornex JF, Bertocchi M, Tronc F, et al. Lung transplantation for pulmonary langerhans' cell histiocytosis: a multicenter analysis. Transplantation 2006;81(5):746-750.

81. Delobbe A, Durieu J, Duhamel A, Wallaert B. Determinants of survival in pulmonary Langerhans' cell granulomatosis (histiocytosis X). Groupe d'Etude en Pathologie Interstitielle de la Société de Pathologie Thoracique du Nord. Eur Respir J 1996;9(10):20022006.

82. Chaowalit N, Pellikka PA, Decker PA, Aubry MC, Krowka MJ, Ryu JH, Vassallo R. Echocardiographic and clinical characteristics of pulmonary hypertension complicating pulmonary Langerhans cell histiocytosis. Mayo Clin Proc 2004;79(10):1269-1275.

83. Le Pavec J, Lorillon G, Jaïs X, Tcherakian C, Feuillet S, Dorfmüller $\mathrm{P}$, et al. Pulmonary Langerhans cell histiocytosis-associated pulmonary hypertension: clinical characteristics and impact of pulmonary arterial hypertension therapies. Chest 2012;142(5):1150-1157.

84. Tazi A, de Margerie C, Naccache JM, Fry S, Dominique S, Jouneau $\mathrm{S}$, et al. The natural history of adult pulmonary Langerhans cell histiocytosis: a prospective multicentre study. Orphanet J Rare Dis 2015;10:30.

85. Kunogi M, Kurihara M, Ikegami TS, Kobayashi T, Shindo N, Kumasaka T, et al. Clinical and genetic spectrum of Birt-Hogg-Dube syndrome patients in whom pneumothorax and/or multiple lung cysts are the presenting feature. J Med Genet 2010;47(4):281-287.

86. Toro JR, Pautler SE, Stewart L, Glenn GM, Weinreich M, Toure O, et al. Lung cysts, spontaneous pneumothorax, and genetic associations in 89 families with Birt-Hogg-Dubé syndrome. Am J Respir Crit Care Med 2007;175(10):1044-1053.

87. Kumasaka T, Hayashi T, Mitani K, Kataoka H, Kikkawa M, Tobino $\mathrm{K}$, et al. Characterization of pulmonary cysts in Birt-Hogg-Dubé syndrome: histopathological and morphometric analysis of 229 pulmonary cysts from 50 unrelated patients. Histopathology 2014; 65(1): $100-110$

88. Goncharova EA, Goncharov DA, James ML, Atochina-Vasserman EN, Stepanova V, Hong SB, et al. Folliculin controls lung alveolar enlargement and epithelial cell survival through E-cadherin, LKB1, and AMPK. Cell Rep 2014;7(2):412-423.

89. Khabibullin D, Medvetz DA, Pinilla M, Hariharan V, Li C, Hergrueter A, et al. Folliculin regulates cell-cell adhesion, AMPK, and mTORC1 in a cell-type-specific manner in lung-derived cells. Physiol Rep 2014;2(8):e12107.

90. Furuya M, Tanaka R, Koga S, Yatabe Y, Gotoda H, Takagi S, et al. Pulmonary cysts of Birt-Hogg-Dubé syndrome: a clinicopathologic and immunohistochemical study of 9 families. Am J Surg Pathol 2012;36(4):589-600.

91. Toro JR, Wei MH, Glenn GM, Weinreich M, Toure O, Vocke C, et al. BHD mutations, clinical and molecular genetic investigations of Birt-Hogg-Dubé syndrome: a new series of 50 families and a review of published reports. J Med Genet 2008;45(6):321-331.

92. Gupta N, Kopras EJ, Henske EP, James LE, El-Chemaly S, Veeraraghavan $\mathrm{S}$, et al. Spontaneous pneumothoraces in patients with Birt-Hogg-Dubé syndrome. Ann Am Thorac Soc 2017;14(5):706713.

93. Onuki T, Goto Y, Kuramochi M, Inagaki M, Bhunchet E, Suzuki K, et al. Radiologically indeterminate pulmonary cysts in Birt-HoggDubé syndrome. Ann Thorac Surg 2014;97(2):682-685.

94. Tobino K, Hirai T, Johkoh T, Kurihara M, Fujimoto K, Tomiyama $\mathrm{N}$, et al. Differentiation between Birt-Hogg-Dubé syndrome and lymphangioleiomyomatosis: quantitative analysis of pulmonary cysts on computed tomography of the chest in 66 females. Eur J Radiol 2012;81(6):1340-1346.

95. Aivaz O, Berkman S, Middelton L, Linehan WM, DiGiovanna JJ, Cowen EW. Comedonal and cystic fibrofolliculomas in Birt-HoggDube syndrome. JAMA Dermatol 2015;151(7):770-774.

96. Pavlovich CP, Grubb RL, Hurley K, Glenn GM, Toro J, Schmidt LS, et al. Evaluation and management of renal tumors in the BirtHogg-Dubé syndrome. J Urol 2005;173(5):1482-1486.

97. Tobino K, Gunji Y, Kurihara M, Kunogi M, Koike K, Tomiyama $\mathrm{N}$, et al. Characteristics of pulmonary cysts in Birt-Hogg-Dubé syndrome: thin-section CT findings of the chest in 12 patients. Eur J Radiol 2011;77(3):403-409.

98. Gupta N, Seyama K, McCormack FX. Pulmonary manifestations of Birt-Hogg-Dubé syndrome. Fam Cancer 2013;12(3):387-396.

99. Menko FH, van Steensel MA, Giraud S, Friis-Hansen L, Richard S, Ungari S, et al. Birt-Hogg-Dubé syndrome: diagnosis and management. Lancet Oncol 2009;10(12):1199-206.

100. Gupta N, Langenderfer D, McCormack FX, Schauer DP, Eckman MH. Chest computed tomographic image screening for cystic lung diseases in patients with spontaneous pneumothorax is cost effective. Ann Am Thorac Soc 2017;14(1):17-25.

101. Stamatakis L, Metwalli AR, Middelton LA, Marston Linehan W. Diagnosis and management of BHD-associated kidney cancer. Fam Cancer 2013;12(3):397-402.

102. Nicholson AG. Lymphocytic interstitial pneumonia and other lymphoproliferative disorders in the lung. Semin Respir Crit Care Med 2001;22(4):409-422.

103. Guinee DG. Update on nonneoplastic pulmonary lymphoproliferative disorders and related entities. Arch Pathol Lab Med 2010; 134(5):691-701

104. Cha SI, Fessler MB, Cool CD, Schwarz MI, Brown KK. Lymphoid interstitial pneumonia: clinical features, associations and prognosis. Eur Respir J 2006;28(2):364-369.

105. Hare SS, Souza CA, Bain G, Seely JM, Gomes MM, Quigley M. The radiological spectrum of pulmonary lymphoproliferative disease. Br J Radiol 2012;85(1015):848-864.

106. Gupta N, Wikenheiser-Brokamp KA, Fischer A, McCormack FX. Diffuse cystic lung disease as the presenting manifestation of Sjögren syndrome. Ann Am Thorac Soc 2016;13(3):371-375.

107. Swigris JJ, Berry GJ, Raffin TA, Kuschner WG. Lymphoid interstitial pneumonia: a narrative review. Chest 2002;122(6):2150-2164.

108. Johkoh T, Ichikado K, Akira M, Honda O, Tomiyama N, Mihara N, et al. Lymphocytic interstitial pneumonia: follow-up CT findings in 14 patients. J Thorac Imaging 2000;15(3):162-167.

109. Dufour V, Wislez M, Bergot E, Mayaud C, Cadranel J. Improvement of symptomatic human immunodeficiency virus-related lymphoid interstitial pneumonia in patients receiving highly active antiretroviral therapy. Clin Infect Dis 2003;36(10):e127-e130.

110. Chew KM, Clarke MJ, Dubey N, Seet JE. Nodular pulmonary amyloidosis with unusual, widespread lung cysts. Singapore Med J 2013;54(5):e97-e99. 


\section{Diffuse Cystic Lung Diseases}

111. Baqir M, Kluka EM, Aubry MC, Hartman TE, Yi ES, Bauer PR, Ryu JH. Amyloid-associated cystic lung disease in primary Sjögren's syndrome. Respir Med 2013;107(4):616-621.

112. Randall RE, Williamson WC, Mullinax F, Tung MY, Still WJ. Manifestations of systemic light chain deposition. Am J Med 1976; 60(2):293-299.

113. Buxbaum J, Gallo G. Nonamyloidotic monoclonal immunoglobulin deposition disease. Light-chain, heavy-chain, and light- and heavychain deposition diseases. Hematol Oncol Clin North Am 1999; 13(6):1235-1248.

114. Colombat M, Stern M, Groussard O, Droz D, Brauner M, Valeyre D, et al. Pulmonary cystic disorder related to light chain deposition disease. Am J Respir Crit Care Med 2006;173(7):777-780.

115. Girard N, Vasiljevic A, Cottin V, Falchero L, Meyronet D, Thivolet-Bejui F, Cordier JF. Respiratory failure with diffuse bronchiectases and cryoglobulinaemia. Eur Respir J 2008;31(6):1374-1378.

116. Hirschi S, Colombat M, Kessler R, Reynaud-Gaubert M, Stern M, Chenard MP, et al. Lung transplantation for advanced cystic lung disease due to nonamyloid kappa light chain deposits. Ann Am Thorac Soc 2014;11(7):1025-1031.

117. Gupta N, Vassallo R, Wikenheiser-Brokamp KA, McCormack FX. Diffuse cystic lung disease. Part II. Am J Respir Crit Care Med 2015;192(1):17-29.

118. Dziegiel P, Dolilńska-Krajewska B, Dumańska M, Wecławek J, Jeleń M, Podhorska-Okołów M, et al. Coexpression of CD1a, Langerin and Birbeck's granules in Langerhans cell histiocytoses ( $\mathrm{LCH}$ ) in children: ultrastructural and immunocytochemical studies. Folia Histochem Cytobiol 2007;45(1):21-25.

119. Cooley J, Lee YCG, Gupta N. Spontaneous pneumothorax in diffuse cystic lung diseases. Curr Opin Pulm Med 2017;23(4):323333.
120. Pollock-BarZiv S, Cohen MM, Downey GP, Johnson SR, Sullivan E, McCormack FX. Air travel in women with lymphangioleiomyomatosis. Thorax 2007;62(2):176-180.

121. Johannesma PC, van de Beek I, van der Wel JW, Paul MA, Houweling AC, Jonker MA, et al. Risk of spontaneous pneumothorax due to air travel and diving in patients with Birt-Hogg-Dubé syndrome. Springerplus 2016;5(1):1506.

122. MacDuff A, Arnold A, Harvey J, Group BPDG. Management of spontaneous pneumothorax: British Thoracic Society Pleural Disease Guideline 2010. Thorax 2010;65(Suppl 2):ii18-ii31.

123. Singla A, Kopras EJ, McCormack FX, Gupta N. Management of spontaneous pneumothorax and safety of air travel in patients with pulmonary Langerhans cell histiocytosis. Am J Respir Crit Care Med 2017;2017;195:A1591.

124. Wajda N, Gupta N. Air travel-related spontaneous pneumothorax in diffuse cystic lung diseases. Curr Pulmonol Rep 2018;7(2):56-62.

125. Bahmer T, Watz H, Waschki B, Gramm M, Magnussen H, Rabe $\mathrm{KF}$, et al. Reduced physical activity in lymphangioleiomyomatosis compared with COPD and healthy controls: disease-specific impact and clinical correlates. Thorax 2016;71(7):662-663.

126. Araujo MS, Baldi BG, Freitas CS, Albuquerque AL, Marques da Silva CC, Kairalla RA, Carvalho CR. Pulmonary rehabilitation in lymphangioleiomyomatosis: a controlled clinical trial. Eur Respir J 2016;47(5):1452-1460.

127. Taveira-DaSilva AM, Julien-Williams P, Jones AM, Moss J. Incidence of pneumothorax in patients with lymphangioleiomyomatosis undergoing pulmonary function and exercise testing. Chest 2016; 150(1):e5-e8

128. Cooper BG. An update on contraindications for lung function testing. Thorax 2011;66(8):714-723. 